\title{
1. Cultural tourism as a dynamic social practice
}

\section{THE EVOLUTION OF CULTURAL TOURISM}

Recent decades have seen a significant increase in the scale and importance of cultural production and consumption. Tourism has also contributed to these trends, with culture becoming an object of travel for growing numbers of people around the globe, and destinations profiling themselves through their cultural assets to distinguish themselves and attract tourist attention. This combination of culture and tourism, which only relatively recently came to be labelled cultural tourism, has become a global social practice.

The traditional view of cultural tourists as cultured people visiting high culture attractions arose during the Grand Tour, which reached its peak in 19th century Europe. This form of 'conspicuous leisure' (Veblen, 1899) was originally reserved for the social elite, those who could afford to spend long periods of time travelling to complete their cultural education. The democratization of tourism, springing from the package tours organized by Thomas Cook in the mid-19th century, gradually broadened the market for cultural tourism, and opened a wider range of cultural destinations. Cultural tourism was further boosted by the growth of mass tourism during the 20th century, as air travel allowed people to travel further afield and discover new and relatively exotic long-haul destinations.

By the 1990s, cultural tourism had become established as a major segment of global tourism, with the United Nations World Tourism Organization (UNWTO) claiming that 40 per cent of international tourists were cultural tourists (Bywater, 1993). Surging cultural tourism demand was met by a flood of places seeking to put themselves, and their cultures, on the global map. Countries used culture to forge new identities and create homogeneous national cultures. Regions and cities employed culture for economic development, fed by the spending of relatively wealthy visitors. Cultural tourism was also seen as a relatively 'good' form of tourism, with high-spending visitors supporting local cultural heritage and economies (Richards, 2001). The role of cultural tourism in supporting heritage also meant it made an important contribution to the 'heritage boom' in the developed world in the 1980s (Hewison, 1987). 
The 1990s saw increased attention for cultural tourism as an emerging form of mass consumption, and destinations began to tap into the economic potential of this market by opening new museums and monuments. In the 1990s, the growth rate of cultural attractions in Europe outstripped the growth of cultural tourism demand (Richards, 2001), producing an increasingly competitive cultural tourism marketplace. This period also saw the extension of cultural tourism through globalization, raising concerns about the effects of cultural tourism on the places being visited, and the homogenization of local cultures (Kirshenblatt-Gimblett, 1998; Pickel-Chevalier, Violier and Sari, 2016). The contrast between cultural tourism as a supporter and violator of cultures created 'a heated debate between two schools of thought; one is well placed in the anti-globalization camp, who see the destruction of authentic culture and identity by global forces ...., and the other is those who see culture and identity as a worthwhile commodity in the global market' (Debeş, 2011, p. 236).

The growing scale of cultural tourism, its increasing impacts on the people and places visited and the emerging links with questions of cultural heritage and identity led to a shift from management and marketing approaches in research towards more attention from cultural studies and anthropology. This also marked a wider transition as part of the 'cultural turn' in the social sciences, which also had a profound impact on the study of cultural tourism.

\section{The Cultural Turn}

The growth of tourism as a social practice attracted more attention from sociologists and other mainstream social scientists. In the 1980s, studies emerged of the role of culture in supporting different lifestyles or patterns of consumption. The work of French sociologist Pierre Bourdieu (1984) highlighted the role of lifestyle in cultural consumption. He argued that social stratification was not just related to traditional markers such as age, income or social class, but also to lifestyles that distinguished groups in terms of their consumption. Culture played an important role in distinguishing these social groups, for example, between those who consumed high culture and consumers of popular culture. One of Bourdieu's important observations was that the ability to consume culture depended on the skills of the consumer, or the amount of cultural capital they possess. Bourdieu argued that cultural capital was acquired from the habitus, or home environment, and through formal education.

Certain lifestyle groups, and particularly people with a high level of education, were found to consume more high culture than others. These were most likely to visit museums, monuments and cultural performances at home, and they were also frequent cultural tourists (Richards, 1996). In their study of cultural tourists at a Rotterdam museum, Jansen-Verbeke and van Rekom (1996) confirmed that highly educated visitors were very likely to be enticed to travel 
by art museums. Similarly, in Canada and the USA, Silberberg (1995) found the cultural tourism audience to be older, more highly educated, high spending and more likely to be female. He also found that only 15 per cent of tourists were greatly motivated by culture, compared with 20 per cent partly motivated by culture and 20 per cent who were 'accidental cultural tourists'. As we will see in Chapter 2, in this respect, little seems to have changed in the cultural tourism field in recent decades.

As international travel expanded, it also formed part of the lifestyle of those highly educated, high earning people interested in culture. In his seminal volume The Tourist, Dean MacCannell (1976) charted how visitors to Paris and other centres of high culture would celebrate the differentiations of modernity by visiting famous landmarks and sights. John Urry (1990) in The Tourist Gaze argued that people wanted to experience things that were different from their everyday life, and that this was creating a 'culture of tourism' (Craik, 2002). Interest in cultural tourism continued to grow among sociologists and anthropologists, who examined emerging styles of tourism in the developing world (Hitchcock and King, 2003), and the growth of heritage production and commodification in the developed world (Halewood and Hannam, 2001; MacLeod, 2013). Concern emerged for the alteration of local and traditional cultures and their resulting commodification by tourism, often spearheaded by the cultural tourists in search of 'authentic' local culture.

The cultural turn was sharpened by the recognition of culture as an economic force. Studies of the cultural economy in the 1990s often cited tourism as an important driver and as a means for spreading wealth to peripheral or depressed regions. Many economic impact studies demonstrated the important role of tourism in economic development, and culture was seen as an important factor attracting tourists (Smith, 2007). Economists began to demonstrate the important job creation role of cultural tourism, not just for static cultural attractions such as museums, but also for events such as the Edinburgh Festival or Salzburg (Gratton and Richards, 1996).

The economic role of cultural tourism fitted the political climate of the time, spurred on by the liberalization of the 1980s and 1990s, and the rise of Thatcherism and Reaganomics. Heritage developments provided opportunities to support entrepreneurship (Corner and Harvey, 1991) and publicly funded museums were encouraged to earn more of their own income (McDonald, 1998). The need for cultural institutions to find new audiences in the face of economic austerity also led them to adopt a more marketing-orientated approach, in which tourism became an attractive and lucrative market.

Cities began to feel the cold winds of austerity as globalization removed the relative protection of the nation state. City centres became hubs for cultural development (Zukin, 1995), and cultural resources were employed in the competitive struggle to attract more consumers, tourists and attention. New 
postmodern museums and cultural attractions began to emerge, stimulated by increasingly fragmented consumer markets and demand for greater interactivity and involvement. New areas of cities were highlighted as culturally interesting places to visit, leading to what Maitland (2007) termed 'new tourist areas'. These were often based on ethnic diversity and the novelty provided by everyday life rather than the glass display cases of the high culture museum.

In the volume Cultural Attractions and European Tourism (Richards, 2001), we charted the spread of cultural tourism, with a growing range of must-see sights fed by bodies promoting culture for a range of different reasons. As de Haan (1997) noted, the increase in cultural tourism in this period did not reflect increasing cultural interest on the part of consumers so much as a growing tourist market meeting a rising tide of cultural provision. This fed a spiral of cultural tourism growth, where the arrival of visitors to consume new attractions was used to justify the construction of more attractions, therefore stimulating more supply-driven cultural tourism. In the case of Hong Kong, for example, $\mathrm{Ng}$ (2002) argues that efforts to diversify the tourism product with new cultural attractions and events led to a 'Cultural Turn of the Tourism Industry', which transformed tourism into a cultural practice.

Growth in cultural tourism was also linked to the shift towards the symbolic economy. Guy Debord (1967) had already announced the advent of the Society of the Spectacle, and spectacular consumption stimulated the growth of cultural destinations. George Ritzer (1999) noted that the means of production had now been transformed into the means of consumption, based on the creation of new 'Cathedrals of Consumption'. Examples of these included the Pompidou Centre in Paris, the Bilbao Guggenheim Museum and the Massachusetts Museum of Contemporary Art (MASS MoCa) in North Adams. The growth of cultural tourism generated more academic analyses of demand for museums and other cultural sites, including studies by Richard Prentice, Duncan Light and Nick Merriman in the UK, Greg Ashworth and Wil Munsters in the Netherlands and Alf Walle in the USA.

Growing research on cultural tourism production and consumption stirred a realization that these processes were intimately linked (Richards, 1996). Gradually, the outlines of what became the experience industry began to be discernible, with the emergence of new 'experience makers', including art historians, journalists, media commentators, gallery owners and cultural tour operators (Richards, Goedhart and Herrijgers, 2001).

\section{The Mobilities Turn}

The 1990s saw continued global expansion of tourism and cultural consumption, and by the turn of the Millennium, the volume of international tourism had increased to almost 690 million arrivals, a growth of over 50 per cent 
compared with 1990. This expansion was supported by increased tourism infrastructure, including airports, hotels and attractions. This generated attention for the growth of 'non-places', including airports and motorways, which are designed for constant motion (Augé, 1995), while Castells (1996) identified the emergence of a global 'space of flows' being created by the network society. It was against this background that John Urry (2000) launched the mobilities paradigm. Some argued that mobilities meant 'the end of tourism' (Gale, 2009), but hindsight suggests the opposite - there were more tourists being more mobile than ever. Cultural tourism also took on a more global dimension, as Boniface and Fowler (2002) described in their analysis of heritage tourism in the 'global village'.

Globalization also drew more attention to cultural differences and their consequences. Cultural diversity, in particular, came to be seen as a stimulus for creativity, innovation and growth. The nascent network of cultural observatories, such as Interarts in Barcelona and Fondazione Fitzcarraldo in Turin, began to chart the consequences of the growing mobility of culture and people, not just in terms of cultural tourism, but also social cohesion, cultural outreach and urban identities. Pioneers such as Eduard Delgado, founder of Interarts, argued for a new vision of cultural plurality and more attention for regional and peripheral cultures, which could also increase their visibility and revive their traditions through cultural tourism (Belda and Laaksonen, 2001). Interarts also convened an international group of researchers to start the discussion that produced the volume Cultural Tourism: Global and Local Perspectives (Richards, 2007).

These efforts marked a realization that globalization, seen by authors such as Augé (1995) as erasing culture and difference, was itself creating new forms of local differentiation. This 'glocalization' trend (Robertson, 1994) marked the increasing resistance of local places to the forces of globalization and the eradication of tradition by the forces of modernity. This was part of the process described by Nijman (1999, p. 148) as 'cultural globalization' or 'acceleration in the exchange of cultural symbols among people around the world, to such an extent that it leads to changes in local popular cultures and identities'. Nijman also argued that cultural globalization was dependent on an expanding culture of consumption.

As Richards (2007) observed, the globalization of cultural tourism was part of this process. As culture became the ubiquitous global object of tourism consumption, it also produced a counter movement towards the local. If 'McGuggenheimization' produced an aesthetic of culture as a global branded good, differentiation had to be sought in the local, the everyday. After all, once everywhere had a Guggenheim, what would be the point of going there? A similar trend began to be recognized in the field of intangible culture, with 
a proliferation of events and festivals around the globe. Places everywhere were suddenly the victims of 'festivalization' (Häussermann and Siebel, 1993).

These shifts produced debates about the meaning of cultural tourism. What could cultural tourism mean in a postmodern world of global cultural brands and copycat events? If we could no longer be sure about the authenticity of places based on appeals to originality, as MacCannell (1976) had suggested, then perhaps the meaning of cultural tourism could be found in a particular style of consumption?

By the turn of the Millennium, there were arguably both grounds for pessimism and optimism (Richards, 2007, p. 293).

In the view of some, local authenticity is rapidly being replaced by global pastiche, and local communities seem powerless to stop this process. In the view of others, local communities still have the power to create new and authentic forms of culture, which can satisfy the visitor as well as strengthening local identity. This division seems to mirror wider debates about the rise of 'cultural pessimism' .... linked to environmental, moral, intellectual and political narratives of decline in the "postmodern' world at the end of the 20th century.

\section{The Performative Turn}

The performative turn had its origins in the work of Goffman (1959) and Turner (1969). Goffman also influenced the work of MacCannell (1976) on staged authenticity, but the performative turn took a long time to filter through to mainstream tourism studies.

Harwood and El-Manstrly (2012) reviewed the performative turn in tourism, and concluded that it 'attempts to explain practices through the act of something being performed'. They identifed different uses of the term, including transformation, enactment, being, negotiation and efficiency. One of the first extensive studies of cultural tourism performance was Edensor's (1998) research on the Taj Mahal, an iconic World Heritage Site in India. Edensor identified different performance dimensions:

1. Spatial and temporal (for example, the stage on which performances take place);

2. The regulation of the stage (for example, managing boundaries and choreography);

3. The accomplishment of the performance itself (related to the perceptions of the audience and the performers).

This analysis reveals that the interactions between tourists and tourism providers, and between tourists themselves, were becoming central to the performance of tourism. Edensor also distinguished two basic types of performance 
spaces: homogeneous and heterogeneous. The homogeneous spaces are those produced by or for tourism, which exclude the local (such as hotels and attractions). Heterogeneous spaces, on the other hand, are not specifically designed for tourist use, but shared between residents and visitors, and therefore have disorganized and emergent qualities. Other studies around this time also emphasized the performance qualities of tourism in different contexts, such as backpacking and local gastronomy (Diekmann and Hannam, 2012; Noy, 2008; Ren, 2010). Valtonen and Viejola (2011, p. 176) noted a paradigmatic shift in the conceptualization of agency in tourism, with 'the shift from the gaze to the body..., from authenticity to performatively ..., and from representations to everyday habits and practices'. More attention was paid to material aspects of tourism practices, particularly by those following an actor-network (ANT) approach (van der Duim, 2007). The performative turn has also produced a stronger link between tourism and ritual - a point we return to in Chapters 4 and 5.

Growing attention for performance led tourism scholars to connect cultural tourism more strongly with the everyday, shifting attention away from the symbolic to the embodied and collaborative (Russo and Richards, 2016). Performance and creativity were also highlighted in the 'creative turn'.

\section{The Creative Turn}

The creative turn emerged at the end of the 1990s with growing calls from policy makers and consultants to generate economic value from creativity and the rapid growth of the creative industries. Creativity was also important in the development of the experience economy, where the creation of value arguably depended on narrative, theming and performance. Cities and regions began to profile themselves as creative places that could attract the creative class (Florida, 2002). Richards and Wilson (2006) identified three basic forms of creative experiences in tourism - spaces, spectacles and creative tourism. Creative spaces include creative and cultural clusters where creative producers and artisans help provide creative environments for tourism consumption (Marques and Richards, 2014). Creative spectacles include iconic buildings and shows staged by creative companies such as Cirque du Soleil. Creative tourism originally emerged as a concept related to small-scale courses and workshops showcasing the creativity of the destination, but gradually expanded to cover a wider range of practices (see Chapter 5).

Kjær Mansfeldt (2015) characterizes the creative turn as being more pragmatic than the performative or mobilities turn. The creative turn responded to, but also extended, the concept of cultural tourism. The concept of 'creative tourism' (Richards and Raymond, 2000) identified a reaction against standardized and unengaging cultural tourism experiences in the face of globalization 
and the serial reproduction of culture. At the same time, creative tourism, or the active involvement of tourists in the creative life of the places they were visiting, also provided new possibilities for creative, more fulfilling cultural tourism experiences.

Creative tourism also emphasized relationality, with tourists actively involved in the co-creation of their own experiences, together with producers (Binkhorst and Den Dekker, 2009). Creative tourism incorporates elements of the other tourism turns: emphasizing the everyday, the intangible, the spontaneity of creative experience, and mundane as opposed to specialized tourist spaces. This heralded an important repositioning of the 'local' with respect to tourism - and the local becoming a new arbiter of authenticity (see Chapter 4).

The creative turn marked a growing integration of tourism and creativity, particularly through the growth of the creative economy (OECD, 2014) and increasing references to 'cultural and creative tourism' (Carvalho, Ferreira and Figueira, 2016). Using the creative industries as a means of boosting the economy and attracting visitors arguably had advantages over more traditional cultural tourism strategies (Richards and Wilson, 2007). The creative industries have a more dynamic image than the traditional, staid image of high culture, and they are broader in scope, also encompassing sectors with high knowledge content and levels of innovation. The new Millennium therefore witnessed many developments that integrated tourism and the creative industries. The most prominent of these were the creative districts that sprung up around the world (Marques and Richards, 2014), and which have been developed into mega-attractions in China (see Chapter 3). Value was added to tourism facilities using design, including design hotels (Strannegård and Strannegård, 2012), design districts (Koskinen, 2009) and iconic wineries built by starchitechts (Webb, 2005).

The creative turn helped to drive new spatial distributions of tourism in both cities and rural areas, as described in Chapter 3. It also stimulated the development of new networks and clusters related to creativity and tourism. These included the global Creative Tourism Network (Couret, 2015) and the CREATOUR project in Portugal (Bakas and Duxbury, 2018; Duxbury and Richards, 2019).

\section{The Curatorial Turn}

The most recent turn in cultural tourism thinking comes from art. The curatorial turn was first signalled in museum studies in the 1980s (O'Neill, 2007). It represents a shift in the system of artistic value creation away from the traditional intermediation role of the art broker or the gallerist towards the curator, who exercises cultural power by selecting 'the value to come', or sources of future value (Venturi, 2018). In performing the role of the selector, the curator 
indulges in a process of 'stylistic innovation' (Wijnberg, 2004), or presenting something new in a way that enhances its future value. For the curator, this involves selecting emerging artists whose work is not currently valued (or selected) by others, and essentially betting on their work to increase in value. In tourism, curation is linked to the identification of places or attractions that are currently underrated or undervalued, which can be harnessed to stimulate future tourism growth (such as the 'cool neighbourhoods' identified in Chapter 3).

The art of curation has become essential in the digital age, with its morass of unorganized information. Content curators act as 'trusted guides', helping us to understand the world around us and ourselves: 'Culturally, these curated resources are not just shortcuts to the "essence" of something, but they also shape and define the character, the perimeter of who we are, of what we are interested in, what we like, give value to and seek' (Good, 2017, p. 7).

Good (2017) argues that content curators act as gatekeepers to cultural portals, and as 'multifaceted lighthouses' scanning the digital landscape for places, things and people deemed worthy of attention. In this sense, cultural curation also becomes an act of placemaking, highlighting locations that tourists can identify with and where they can experience meaningful things. Content curation, as a process of ordering information to generate value, is spawning the growth of 'content curation sites' in tourism (Miralbell, Alzua-Sorzabal and Gerrikagoitia, 2013). There are many examples in cultural tourism, such as Culture Trip in the UK, the Cultural Curator, Cultural Tourism DC in Washington and the Creative Tourist platform. The latter features 'creative things to do in Manchester and the North' of England and also advises other destinations on cultural and creative tourism development. These sites create value by ordering information and through their role as selectors. Cultural curation sites highlight the people responsible for the selection, staking their claim to the position of content organizer and gatekeeper. The curatorial turn marks a shift from exchange value to relational value.

The eventification of cultural tourism also allows curators to select specific moments that are significant in cultural consumption. This is most evident in the staging of exhibitions that present 'once in a lifetime' opportunities to see particular works or curated selections of art. But it also underpins selections of festivals to visit or times to be in specific cities and places. The curator, by paying attention to a specific location at a certain time, signals an increase in the value of that place, and hence stimulates visitation to destinations that are 'cool' at a specific moment (Pappalepore, Maitland and Smith, 2014).

The effects of the curatorial moment were charted by Richards (2010) in his dissection of the dilemma posed for Canadian architectural critic Sanford Kwinter in October 1997. Rather than attending the opening of the Bilbao 
Guggenheim, he was at the fiftieth anniversary re-enactment of the first supersonic flight by Chuck Yeager in the Mojave Desert. Kwinter chose the desert:

because we believe in shock waves, we believe them to be part of the music of modernity, not something to watch a ribbon be cut from, but something to feel with our diaphragms, eardrums, genitals and the soles of our feet. We wanted to be in the desert badlands that day with nothing but the sun, the baked dirt, the pneumatic tremors, and the unbroken horizon. (Kwinter, 2010, p. 89)

Richards explains this in curatorial terms: Kwinter had decided that the Guggenheim represented the past, an event that would attract his fellow critics in droves, whereas the desert represented the value to come. In the end, however, Kwinter's bet on a supersonic future proved a poor one, curtailed less than three years later with the crash of Air France Concorde Flight 4590 near Paris (Richards, 2010). Many cultural tourism curators seem to follow Kwinter's strategy: they look for places that are currently undiscovered, or 'under the radar' of the mass cultural tourist and other selectors, but which are likely to become more popular in future, such as Dundee in Scotland and Tirana in Albania (Lonely Planet, 2018).

Each of the turns outlined above have marked changes in the position and nature of cultural tourism, with concomitant shifts in the actors and structures involved, requiring new research approaches. This book adopts a practice approach as explained in the next section.

\section{TOWARDS NEW APPROACHES TO CULTURAL TOURISM}

In recent years, the theory and practice of cultural tourism have undergone significant transformation. From a simple addition of 'culture' and 'tourism' in the 1980s, cultural tourism began to be perceived and analysed as a self-contained field, and perspectives on cultural tourism have also responded to the different turns in social theory. Initial academic interest in the field can be traced back to the cultural turn, with growing attention for the stratification and signification of cultural tourism consumption. The mobilities turn focussed attention on the constant movement of cultural tourists and problematized the original concept of the tourist gaze. The performative turn generated more attention for the agency of the cultural tourist, who was not just a consumer but also a performer of cultural experiences. The creative turn has also highlighted the multiplication of new identities and roles in cultural tourism, and the rise of the 'local' as a category of 'authentic' cultural tourism experience.

The successive academic turns, the expansion of cultural tourism demand, the supply of cultural sites and events and the growing range of actors pro- 
moting cultural tourism have also stimulated a growing body of knowledge. From isolated academic studies in the 1980s, the cultural tourism literature has expanded to almost 9000 publications a year in 2019, almost 10 per cent of the total publication output in the field of tourism (Richards, 2018). This growing output covers a number of main themes, including cultural tourism as a form of cultural consumption, motivations for cultural tourism, the economic aspects of cultural tourism, the relationship between tourism and cultural heritage, the growth of the creative economy, and the links between anthropology and cultural tourism.

These studies show a tendency to concentrate either on the consumption of culture (motivation, behaviour) or the production of cultural experiences for tourists (authenticity, satisfaction). However, as the previous discussion has emphasized, it is increasingly difficult to separate consumption and production. In particular, the idea of a relatively passive tourist gazing on the sights offered to them by producers in the tourism industry came under increasing scrutiny. The performative turn shed light on the relatively active role that many tourists have in constructing their own experience (Ek, Larsen, Hornskov and Mansfeldt, 2008). By the turn of the Millennium, there was also more attention for co-creation between producers and consumers to develop tourism experiences (Binkhorst and Den Dekker, 2009; Campos, Mendes, Valle and Scott, 2018). Providers realized they needed to get closer to tourists to understand their needs in fast-moving consumer markets, and that this could be achieved by enlisting them in the experience production process. Vargo and Lusch (2008) outlined similar changes in the emergence of service dominant logic, and the concomitant shift from using operand (tangible resources) to operant (skills and knowledge) resources.

One of the changes that facilitated co-creation was the shift towards intangible cultural resources in tourism experiences (OECD, 2014). This enabled consumers to contribute more of their own knowledge and skills to the experience (Richards and Wilson, 2006). The rise of the Internet and digital technologies also transformed the information flows in tourism from a system of broadcast by producers (Poon, 1993) towards 'new tourists' as co-producers of information. As tourists began providing information to their peers, they also penetrated areas that suppliers had found difficult to reach. Tourists began to consume more areas of 'everyday life', or the elements of the destination that fell outside the framing activities of the tourist industry. The ability of visitors to expand the scope of cultural content produced a more fragmented landscape of cultural tourism demand, with many new niches emerging (Richards, 2011). These were exploited by an army of new cultural and creative intermediaries eager to offer new experiences, leading to innovation and even more fragmentation. This more diverse cultural tourism scene also became more democra- 
tized, as the framing power of the tourism industry declined, and new cultural forms began to challenge the previous hegemony of high culture.

The changing nature of cultural tourism consumption and production was recently summarized in the UNWTO Report on Tourism and Culture Synergies (2018). This signalled some important shifts in the relationship between tourism and culture:

1. A shift from tangible to intangible heritage in cultural tourism consumption and production;

2. A growing focus on everyday life, or 'living like a local' (Russo and Richards, 2016);

3. Fragmentation of cultural tourism into a series of niches, such as heritage tourism, art tourism, gastronomy tourism, film tourism and music tourism (Richards, 2011);

4. An eventification of cultural tourism supply and demand as a means of generating attention and spreading demand (Richards, 2013);

5. The rise of new intermediaries and systems of curation (Tribe, 2008);

6. A shift from elite to mass culture and the rise of new forms of distinction;

7. A broadening concept of culture as an object of tourism.

This growing complexity means that traditional discipline-based approaches to cultural tourism often fail to capture the nuances of the relationships between the actors and structures in the cultural tourism field. As Bargeman and Richards (2020) have outlined, there is a need to take a broader, more integrated approach to the study of tourism to resolve the actor-structure dichotomy and deal with increasing fragmentation of demand and supply and the rise of co-creation. Such a new approach also needs to deal with the question of how consumers and producers become entrained into practices, such as cultural tourism, and why they maintain or cease their participation.

Three basic moves are enfolded in this practice-based approach. Firstly, a practice view of tourism integrates actor and structure-related factors, seeing practices as routine-based configurations of activities shared by groups of people as part of their everyday life, through which social structures are produced, which in turn guide the actions of participants in the practice. The actors include all those individuals and organizations who can influence or who are influenced by the (cultural tourism) practice. Previous distinctions between producers and consumers in tourism therefore fade: both are enlisted in the creation and maintenance of the practice.

Secondly, we view social practices as a form of interaction ritual (Collins, 2004), which allows us to explain motivations for joining and adhering to tourism practices. Building on studies of leisure practices by scholars from Tilburg University (e.g. van der Poel, 1997), and shaped as a research agenda 
by Richards (2010), this work has been consolidated and extended by a wider group of researchers also incorporating Breda University of Applied Sciences (e.g. Bargeman, Richards and Govers, 2018; Richards, 2014; Simons, 2019, 2020).

Thirdly, we attempt to address a weakness in Collins' (2004) original view of rituals or practices by paying attention not just to the conditions that produce emotional energy, but also the contexts and the dynamics of practices. Chapter 3 examines the contexts of cultural tourism practices in more detail, highlighting the way in which the locations and times of cultural tourism practices affect, and are affected by, the actors involved. Based on the work of Shove and her collaborators (Shove, Pantzar and Watson, 2012), we also examine how the dynamics of practices evolve through the interaction of competences, materials and meaning.

As Richards (2011) outlines, Shove and Pantzar (2005) argue that a focus on practices produces a new set of research questions, which also apply to the study of cultural tourism:

1. What it means to participate in a practice;

2. How enthusiasms develop and flourish;

3. The demands that practices make of those who follow them;

4. Specific mechanisms of attraction and defection for practitioners;

5. The relationship between individual practitioners and the unfolding entity of the practice.

These are questions that we will also develop through the remainder of the book, seeking to explain how cultural tourism practices come to be through the interactions of actors and structures. Chapter 2 considers the wide range of different actors involved in cultural tourism practices, and how they collaborate and interact to co-create cultural tourism experiences. The actions of these different actors are heavily influenced by social structures (such as markets and regulatory frameworks) and take place in different spatial and temporal contexts. In Chapter 3, we consider how such contexts shape cultural tourism activities, and how they are in turn shaped by the dynamics of cultural tourism. Cultural tourism practices also have a range of consequences or outcomes, both intended and unintended. These include economic benefits to local economies and the cultural system, but also overcrowding at major cultural sites and threats to 'authenticity'. These issues are dealt with in Chapter 4, which also provides a new practice-based definition of cultural tourism. This chapter also develops a model incorporating Collins' (2004) perspectives on interaction rituals, which emphasize relationality and embodiment through physical co-presence and processes of entrainment among groups of actors. Chapter 5 illustrates some of these cultural tourism rituals, including placemaking, 
creative tourism, photography, gastronomy and eventification, which are often manifested as bundles of practices - in 'new urban tourism', for example. In the final chapter, we look towards the future, sketching emerging research agendas relating to a practice approach. We also pay attention to the issue of interrupted practices: drawing on the experience of the Covid-19 pandemic, which suggests the future of cultural tourism might not be so routine as suggested by traditional practice analysis.

The structure of the text is shown in Figure 1.1, with a progressive focus on different elements of the cultural tourism practice, from actors in Chapter 2 to the contexts of practices in Chapter 3. The interaction of actors and context in the practice serve to generate consequences or effects, which are analysed in Chapter 4. One of the important consequences is the development and maintenance of the practice itself, which are dealt with in the context of Collins' interaction ritual in Chapter 5.

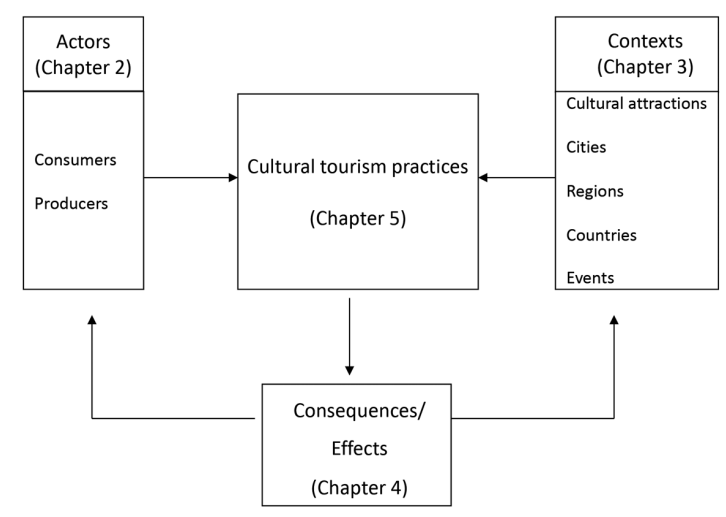

Figure 1.1 Model of cultural tourism practices and structure of the text

\section{REFERENCES}

Augé, M. (1995). Non-places: An Anthropology of Supermodernity. New York: Verso. Bakas, F.E. and Duxbury, N. (2018). Development of rural areas and small cities through creative tourism: the CREATOUR project. Anais Brasileiros de Estudos Turisticos, 8(3), 74-84.

Bargeman, B. and Richards, G. (2020). A new approach to understanding tourism practices. Annals of Tourism Research, 84. https://doi.org/10.1016/j.annals.2020 .102988.

Bargeman, B., Richards, G., and Govers, E. (2018). Volunteer tourism impacts in Ghana: a practice approach. Current Issues in Tourism, 21(13), 1486-501. 
Belda, E. and Laaksonen, A. (2001). Pyrenne: A European Project to Foster Linguistic Diversity and the Role of Tradition in Contemporary Arts Production. Barcelona: Fundacio Interarts.

Binkhorst, E. and Den Dekker, T. (2009). Agenda for co-creation tourism experience research. Journal of Hospitality Marketing \& Management, 18(2-3), 311-27.

Boniface, P. and Fowler, P. (2002). Heritage and Tourism in the Global Village. London: Routledge.

Bourdieu, P. (1984). Distinction: A Social Critique of the Judgement of Taste. London: Routledge.

Bywater, M. (1993). The market for cultural tourism in Europe. Travel and Tourism Analyst, 6, 30-46.

Campos, A.C., Mendes, J., Valle, P.O.D., and Scott, N. (2018). Co-creation of tourist experiences: a literature review. Current Issues in Tourism, 21(4), 369-400.

Carvalho, R., Ferreira, A.M., and Figueira, L.M. (2016). Cultural and creative tourism in Portugal. PASOS. Revista de Turismo y Patrimonio Cultural, 14(5), 1075-82.

Castells, M. (1996). The Information Age, Vol. 1: The Rise of the Network Society. Oxford: Blackwell.

Collins, C. (2004). Interaction Ritual Chains. Princeton, NJ: Princeton University Press.

Corner, J. and Harvey, S. (1991). Enterprise and Heritage: Crosscurrents of National Culture. London: Routledge.

Couret, C. (2015). Collaboration and partnerships in practice: the creative tourism network ${ }^{\circledR}$. In D. Gursoy, M. Saayman, and M. Sotiriadis (eds), Collaboration in Tourism Businesses and Destinations: A Handbook (pp. 191-203). Bingley: Emerald Group Publishing.

Craik, J. (2002). The culture of tourism. In C. Rojek and J. Urry (eds), Touring Cultures: Transformations of Travel and Theory (pp. 123-46). London: Routledge.

Debeş, T. (2011). Cultural tourism: a neglected dimension of tourism industry. Anatolia, 22(2), 234-51.

Debord, G. (1967). The Society of the Spectacle. New York: Zone Books.

De Haan, J. (1997). Het Gedeelde Erfgoed. Den Haag: Sociaal en Cultureel Planbureau.

Diekmann, A. and Hannam, K. (2012). Touristic mobilities in India's slum spaces. Annals of Tourism Research, 39(3), 1315-36.

Duxbury, N. and Richards, G. (2019). A Research Agenda for Creative Tourism. Cheltenham, UK and Northampton, MA, USA: Edward Elgar Publishing.

Edensor, T. (1998). Tourists at the Taj: Performance and Meaning at a Symbolic Site. London: Routledge.

Ek, R., Larsen, J., Hornskov, S.B., and Mansfeldt, O.K. (2008). A dynamic framework of tourist experiences: space-time and performances in the experience economy. Scandinavian Journal of Hospitality and Tourism, 8(2), 122-40.

Florida, R. (2002). The Rise of the Creative Class. New York: Basic Books.

Gale, T. (2009). Urban beaches, virtual worlds and 'the end of tourism'. Mobilities, 4(1), $119-38$.

Goffman, E. (1959). The Presentation of Self in Everyday Life. New York: Anchor Books.

Good, R. (2017). Content curation \& cultural heritage: the social value of selecting and organizing existing content. https://medium.com/content-curation-official-guide/ content-curation-cultural-heritage-5cb602d066af (accessed 18 December 2020).

Gratton, C. and Richards, G. (1996). The economic context of cultural tourism. In G. Richards (ed.), Cultural Tourism in Europe (pp. 71-87). Wallingford: CABI. 
Halewood, C. and Hannam, K. (2001). Viking heritage tourism: authenticity and commodification. Annals of Tourism Research, 28(3), 565-80.

Harwood, S. and El-Manstrly, D. (2012). The performativity turn in tourism. University of Edinburgh Business School Working Paper Series, 12(05), University of Edinburgh Business School.

Häussermann, H. and Siebel, W. (1993). Die Politik der Festivalisierung und die Festivalisierung der Politik. In H. Häussermann (ed.), Festivalisierung der Stadtpolitik: Stadtentwicklung durch große Projekte (pp. 7-31). Wiesbaden: VS Verlag für Sozialwissenschaften.

Hewison, R. (1987). The Heritage Industry: Britain in a Climate of Decline. London: Methuen.

Hitchcock, M. and King, V.T. (2003). Discourses with the past: tourism and heritage in South-East Asia. Indonesia and the Malay World, 31(89), 3-15.

Jansen-Verbeke, M. and Van Rekom, J. (1996). Scanning museum visitors: urban tourism marketing. Annals of Tourism Research, 23(2), 364-75.

Kirshenblatt-Gimblett, B. (1998). Destination Culture: Tourism, Museums, and Heritage. Davis, LA: University of California Press.

Kjær Mansfeldt, O. (2015). The inbetweenness of tourist experiences. PhD thesis, Royal Danish Academy of Fine Arts, Copenhagen.

Koskinen, I. (2009). Design districts. Design Issues, 25(4), 3-12.

Kwinter, S. (2010). Mach 1 (and other mystic visitations). In A.K. Sykes (ed.), Constructing a New Agenda: Architectural Theory 1993-2009 (pp. 80-9). New York: Princeton Architectural Press.

Lonely Planet (2018). Best in Europe 2018. https://www.lonelyplanet.com/articles/best -in-europe-2018 (accessed 18 December 2020).

MacCannell, D. (1976). The Tourist: A New Theory of the Leisure Class. Davis, CA: University of California Press.

MacLeod, N. (2013). Cultural routes, trails and the experience of place. In M. Smith and G. Richards (eds), The Routledge Handbook of Cultural Tourism (pp. 390-5). London: Routledge.

Maitland, R. (2007). Tourists, the creative class and distinctive areas in major cities: the roles of visitors and residents in developing new tourism areas. In G. Richards and J. Wilson (eds), Tourism, Creativity and Development (pp. 95-108). London: Routledge.

Marques, L. and Richards, G. (2014). Creative Districts Around the World. http:// creativedistricts.imem.nl/articles/36/00_Marques_Richards_Creative_Districts complete_book.pdf (accessed 18 December 2020).

McDonald, S. (1998). The Politics of Display: Museums, Science, Culture. London: Routledge.

Miralbell, O., Alzua-Sorzabal, A., and Gerrikagoitia, J.K. (2013). Content curation and narrative tourism marketing. In Z. Xiang and I. Tussyadiah (eds), Information and Communication Technologies in Tourism 2014: Proceedings of the International Conference in Dublin, Ireland, January 21-24, 2014 (pp. 187-99). Cham: Springer Science \& Business Media.

Ng, M.K. (2002). From a 'cultural desert' to a 'cultural supermarket': tourism promotion in Hong Kong. In W.B. Kim and J.Y. Yoo (eds), Culture, Economy and Place: Asia-Pacific Perspectives (pp. 179-218). Anyang: Korea Research Institute for Human Settlements.

Nijman, J. (1999). Cultural globalization and the identity of place: the reconstruction of Amsterdam. Ecumene, 6, 146-64. 
Noy, C. (2008). Traversing hegemony: gender, body, and identity in the narratives of Israeli female backpackers. Tourism Review International, 12(2), 93-114.

OECD (2014). Tourism and the Creative Economy. Paris: OECD.

O'Neill, P. (2007). The curatorial turn: from practice to discourse. In J. Rugg and M. Sedgwick (eds), Issues in Curating Contemporary Art and Performance (pp. 13-28). Bristol: Intellect Books.

Pappalepore, I., Maitland, R., and Smith, A. (2014). Prosuming creative urban areas. Evidence from East London. Annals of Tourism Research, 44, 227-40.

Pickel-Chevalier, S., Violier, P., and Sari, N.P.S. (2016). Tourism and globalisation: vectors of cultural homogenisation? (the case study of Bali). In A.M. Morrison, A.G. Abdullah, and S. Leo (eds), Proceedings of the Asia Tourism Forum, 2016 'A New Approach of Tourism' (pp. 452-7). Paris: Atlantis Press.

Poon, A. (1993). Tourism, Technology and Competitive Strategies. Wallingford: CABI.

Ren, C. (2010). Assembling the socio-material destination: an actor-network approach to cultural tourism studies. In G. Richards and W. Munsters (eds), Cultural Tourism Research Methods (pp. 199-208). Wallingford: CABI.

Richards, G. (1996). Production and consumption of European cultural tourism. Annals of Tourism Research, 23(2), 261-83.

Richards, G. (2001). Cultural Attractions and European Tourism. Wallingford: CABI.

Richards, G. (2007). Cultural Tourism: Global and Local Perspectives. New York: Haworth Press.

Richards, G. (2010). Leisure in the Network Society: From Pseudo-events to Hyperfestivity? https://www.academia.edu/1271795/Leisure_in_the_Network Society (accessed 18 December 2020).

Richards, G. (2011). Rethinking niche tourism in the network society. Paper presented at the ATLAS Annual Conference in Cyprus, November 2011. https:// www.academia.edu/1868914/Rethinking_niche_tourism_in_the_network_society (accessed 18 December 2020).

Richards, G. (2013). Events and the means of attention. Journal of Tourism Research \& Hospitality, 2(2). http://www.scitechnol.com/2324-8807/2324-8807-2-118.pdf (accessed 18 December 2020).

Richards, G. (2014). Imagineering events as interaction ritual chains. In G. Richards, L. Marques, and K. Mein (eds), Event Design: Social Perspectives and Practices (pp. 14-24). London: Routledge.

Richards, G. (2018). Cultural tourism: a review of recent research and trends. Journal of Hospitality and Tourism Management, 36, 12-21.

Richards, G. and Raymond, C. (2000). Creative tourism. ATLAS news, 23(8), 16-20.

Richards, G. and Wilson, J. (2006). Developing creativity in tourist experiences: a solution to the serial reproduction of culture? Tourism Management, 27, 1209-23.

Richards, G. and Wilson, J. (2007). Tourism, Creativity and Development. London: Routledge.

Richards, G., Goedhart, S., and Herrijgers, C. (2001). The cultural attraction distribution system. In G. Richards (ed.), Cultural Attractions and European Tourism (pp. 71-89). Wallingford: CABI.

Ritzer, G. (1999). Enchanting a Disenchanted World: Revolutionizing the Means of Consumption. Thousand Oaks, CA: Pine Forge Press.

Robertson, R. (1994). Globalisation or glocalisation? Journal of International Communication, 1(1), 33-52.

Russo, A.P. and Richards, G. (2016). Reinventing the Local in Tourism: Producing, Consuming and Negotiating Place. Bristol: Channel View Publications. 
Shove, E. and Pantzar, M. (2005). Consumers, producers and practices: understanding the invention and reinvention of Nordic walking. Journal of Consumer Culture, 5(1), 43-64.

Shove, E., Pantzar, M., and Watson, M. (2012). The Dynamics of Social Practice: Everyday Life and How It Changes. London: Sage.

Silberberg, T. (1995). Cultural tourism and business opportunities for museums and heritage sites. Tourism Management, 16(5), 361-5.

Simons, I. (2019). Events and online interaction: the construction of hybrid event communities. Leisure Studies, 38(2), 145-59.

Simons, I. (2020). Changing identities through collective performance at events: the case of the Redhead Days. Leisure Studies, 1-17.

Smith, M.K. (ed.). (2007). Tourism, Culture and Regeneration. Wallingford: CABI.

Strannegård, L. and Strannegård, M. (2012). Works of art: aesthetic ambitions in design hotels. Annals of Tourism Research, 39(4), 1995-2012.

Tribe, J. (2008). The art of tourism. Annals of Tourism Research, 35(4), 924-44.

Turner, V. (1969). The Ritual Process: Structure and Anti-structure. Piscataway, NJ: Transaction Publishers.

UNWTO (2018). Report on Tourism and Culture Synergies. Madrid: UNWTO.

Urry, J. (1990). The Tourist Gaze. London: Sage.

Urry, J. (2000). Beyond Societies: Mobilities for the Twenty-first Century. London: Routledge.

Valtonen, A. and Veijola, S. (2011). Sleep in tourism. Annals of Tourism Research, 38(1), 175-92.

Van der Duim, R. (2007). Tourismscapes: an actor-network perspective. Annals of Tourism Research, 34(4), 961-76.

Van der Poel, H. (1997). Leisure and the modularization of daily life. Time \& Society, 6(2-3), 171-94.

Vargo, S.L. and Lusch, R.F. (2008). Service-dominant logic: continuing the evolution. Journal of the Academy of Marketing Science, 36(1), 1-10.

Veblen, T. (1899). Theory of the Leisure Class: An Economic Study in the Evolution of Institutions. New York: Macmillan.

Venturi, F. (2018). Curating music, articulating value: towards a definition of the curatorial within live new music. https://www.academia.edu/42055917/Curating_Music _Articulating_Value_Towards_a_definition_of_the_curatorial_value_of_live_new music (accessed 18 December 2020).

Wēbb, M. (2005). Adventurous Wine Architecture. Melbourne: Images Publishing.

Wijnberg, N.M. (2004). Innovation and organization: value and competition in selection systems. Organization Studies, 25(8), 1413-33.

Zukin, S. (1995). Culture of Cities. Oxford: Blackwell. 